UDK: 625.7/.8

DOI: https://doi.org/10.24867/14CG09strbac

\title{
УПОРЕДНА АНАЛИЗА КРУЖНИХ И ТУРБО КРУЖНИХ РАСКРСНИЦА ПРИМЕНОМ ВИШЕКРИТЕРИЈУМСКЕ АНАЛИЗЕ
}

\section{COMPARATIVE ANALYSIS OF CONVENTIONAL AND TURBO ROUNDABOUTS USING MULTRICRITERIA ANALYSIS}

\section{Далиа Штрбац, Факултет техничких наука, Нови Сад}

\section{Област - ГРАЂЕВИНАРСТВО}

Кратак садржај - У оквиру овог рада представњене су карактеристике кружних раскрсница и турбо кружних раскрсница, приказане су основе за юихово планирање и пројектовање. Приликом избора типа кружне раскрснице за предметну локацију - Булевар иара Лазара и Фрушкогорске улице у Новом Саду, коришћена је Вишекритеријумска оптимизација (ВКО) $и$ метода Итеративног компромисног рангирања (ИКОР). Као резултат ове методе, могли смо да донесмо одлуку који тип кружне раскрнице је боља алтернатива за нашу предметну локаџију.

Кључне речи: Кружне раскрснище, Турбо кружне раскрснице, Вишекритеријумска анализа

Abstract - This work presents the characteristics of conventional roundabouts and turbo roundabouts and the bases for their planning and design are indicated. When we choosing the type of roundabout for the subject location - Boulevar cara Lazara and Fruskogorska Street in Novi Sad, we use the Multicriteria Optimization and method of Interactive Compromise Ranking (IKOR). As a result of these methods, we were able to make a decision about which type of roundabout is better alternative for the location.

Keywords: Conventional roundabouts, Turboroundabouts, Multicriteria analysis

\section{1. УВОД}

Један од најважнијих делова саобраћајне инфраструктуре су раскрснице, јер оне спајају и раздвајају саобраћајне токове, тако да су ова места у путној мрежи од велике важности. Раскрсница треба, пре свега, да обезбеди сигурност свих учесника у саобраћају, као и задовољавајући проток и квалитет саобраћаја, а да геометријске карактеристике буду изведене у складу са важећим прописима и правилима.

Како су кружне раскрснице постајале популарније, тако су се развијали и нови типови кружних раскрсница. Из потребе да кружне раскрснице буду што безбедније, а да самим тим квалитет протока саобраћајане буде смањен него, напротив, повећан, настале су турбо кружне раскрснице.

\section{НАПОМЕНА:}

Овај рад проистекао је из мастер рада чији ментор је био доц. др Милош Шешлија.
Да бисмо изабрали одговарајући тип кружне раскрснице, који ће испуњавати задате циљеве за предметну локацију на углу Булевара цара Лазара и Фрушкогорске улице, приликом избора користили смо вишекритеријумску анализу.

\section{2. КРУЖНЕ РАСКРСНИЦЕ}

Кружна раскрсница је назив за врсту раскрснице у друмском саобраћају која има несметан ток саобраћаја. Односно, кружна раскрсница је раскрсница у којој се саобраћај одвија кружно, у смеру супротном од смера казаљке на сату.

\section{3. ПРОЈЕКТНО-ТЕХНИЧКИ ЕЛЕМЕНТИ КРУЖНИХ РАСКРСНИЦА}

Основни елементи кружних раскрсница су:

- кружни коловоз;

- централно острво које се састоји из прегазног, условно прегазног и непрегазног дела;

- краци кружне раскрснице;

- спољашњи пречник кружне раскрснице;

- унутрашњи пречник кружне раскрснице;

- уливне и изливне саобраћајне траке;

- уливни и изливни радијуси;

- разделна острва.

Пројектно-технички елементи кружних раскрсница подразумевају смернице за пројектовање и обликовање наведених елемената као и њихове препоручене вредности, односно димензије.

\section{3. ТУРБО КРУЖНЕ РАСКРСНИЦЕ}

Турбо кружне раскрснице развиле су се из двотрачних кружних раскрсница због потребе повећања сигурности саобраћаја у кружном току.

Турбо кружна раскрсница је посебна врста вишетрачне кружне раскрснице, при којој су саобраћајни токови међусобно одвојени бетонским префабрикованим елементима који спречавају промену возне траке (преплитање саобраћајних токова) у кружном току.

Када се возач на уливу у турбо кружну раскрсницу одлучи на којем изливу ће напустити кружну раскрсницу, одлуку више није могуће мењати, јер овај тип кружних раскрсница не дозвољава промену возних трака у кружној раскрсници. 


\section{5. ПРОЈЕКТНО-ТЕХНИЧКИ ЕЛЕМЕНТИ ТУРБО КРУЖНИХ РАСКРСНИЦА}

Елементи турбо кружних раскрсница су начелно исти као код класичних кружних раскрсница, међутим јављају се специфични елементи којих код класичне кружне раскрснице нема, а то су префабриковани бетонски елеменати (денивелатори) који спречавају преплитање саобраћајних токова на кружном коловозу и елеменат "шпиц" који је уређен почетак елемента за спречавање преплитања саобраћајних токова на кружном коловозу турбо кружне раскрснице.

Геометријски облик централног острва турбо кружне раскрснице се формира помоћу ткз. "турбо блока". То је блок или скуп свих потребних полупречника које је потребно на одређен начин заротирати и на тај начин добити возне линије, односно саобраћајне траке.

\section{6. БЕЗБЕДНОСТ}

Повећање безбедности применом кружних раскрсница јавља се као последица смањења броја конфликтних тачака у односу на класичне раскрснице са директним укрштањем токова са 32 на 24 конфликтне тачке, као и смањена брзине како при уласку, тако и током вожње кроз кружну раскрсницу, која је условљена геометријским обликом кружне раскрснице.

Конфликтне тачке су места на којима се трасе два учесника у саобраћају укрштају, спајају или раздвајају. Број конфликтних тачака зависи од типа кружне раскрснице и броја улазних и излазних саобраћајних токова.

Турбо кружне раскрснице у поређењу са класичним двотрачним кружним раскрсницама смањују број конфликтних тачака са 24 на 14.

\section{7. КАПАЦИТЕТ}

Капацитет кружне раскрснице изражава се преко капацитета њених појединачних прилаза. Капацитет целе раскрснице се не одређује.

Капацитет прилаза кружне раскрснице је маскималан саобраћајни захтев који у конкретним условима геометрије и интензитета приоритетног саобраћајног тока може током одређеног периода да се прикључи кружном току раскрснице.

За сваку нову или реконструисану кружну раскрсницу потребно је проверити њену проточност.

\section{8. ВИШЕКРИТЕРИЈУМСКА АНАЛИЗА}

Вишекритеријумска анализа истражује начине како да ce без упрошћења полазног проблема одреди компромисно решење, пошто строго оптимално решење због конфликта критеријума не постоји. Најчешће је то процес вредновања скупа решења могућих алтернатива у односу на скуп одабраних критеријума, односно циљева.

Потреба за доношењем одлуке присутна је у свим доменима егзистенције, од појединца до најразличитијих организованих облика људи и друштва.
Доношење неке одлуке подразумева избор најбоље, односно оптималне алтернативе, која представља комбинацију максималног учинка и минималних трошкова.

Циљ Вишекритеријумске оптимизащије је доношење конкретне одлуке, али не најповољнијег решења које је боље од свих других алтернатива за све критеријуме, већ алтернатива која је добра за највећи број задатих критеријума.

Методе вишекритеријумске оптимизације (ВКО) које ћемо представити и применити у овом раду су:

- Компромисно програмирање

- Вишекритеријумско компромисно рангирање алтернативних решења

\section{9. ИСТРАЖИВАЊЕ КРОЗ ВРЕДНОВАЊЕ АЛТЕРНАТИВНИХ РЕШЕЫА ПРИЛИКОМ ИЗБОРА ТИПА КРУЖНЕ РАСКРСНИЦЕ ЗА ОДРЕБЕНУ ЛОКАЦИЈУ}

9.1. Опис и локација будуће кружне раскрснице на углу Булевара цара Лазара и Фрушкогорске улиище

У систему основне уличне мреже Новог Сада предметна раскрсница се налази на примарној саобраћајној мрежи града.

Планирана је изградња кружне раскрснице на углу Булевара цара Лазара и Фрушкогорске улице. Задатак је извршити вредновање различитих алтернативних решења, односно типова кружних раскрсница уз одређивање оптималне варијанте. Вредновање ће се извршити за два типа раскрснице, кружну и турбо кружну раскрсницу у циљу добијања решења.

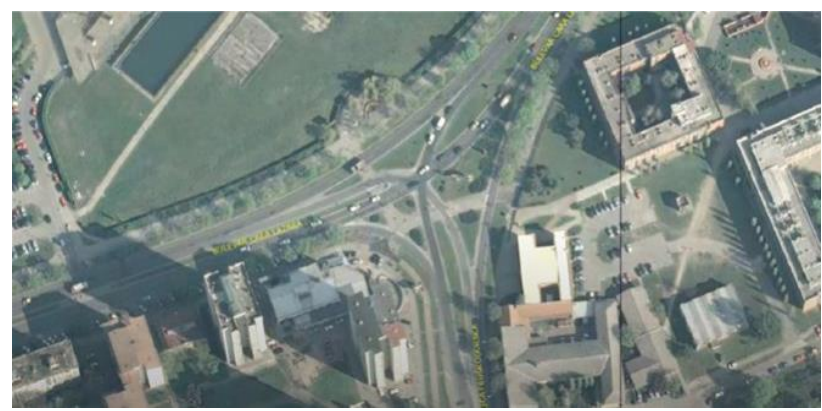

Слика 1. Постојаће стање раскрснище на углу

Булевара циара Лазара и Фрушкогорске улице

9.2. Истраживање кроз вредновање алтернативних решења приликом избора типа кружне раскрснице на углу Булевара цара Лазара и Фрушкогорске улице

У раду су анализирана два типа кружних раскрсница на истој предметној локацији. Прво алтернативно решење које је анализирано је двотрачна кружна раскрсница (КР), односно кружна раскрсница са две саобраћајне траке унутар кружног тока, која ће у наставку бити означена А2, док друго алтернативно решење представља турбо кружну раскрсницу (ТКР), која припада групацији кружних раскрсница са одређеним изменама која су објашњена у предходним поглављима и која ће у наставку бити означена A1. 
Критеријуми који су узети у анализу су следећи:

- $f_{1}$ - капацитет раскрснице,

- $f_{2}$ - цена коштања изградње раскрснице,

- $f_{3}$ - број конфликтних и колозионих тачака,

- $f_{4}$ - сигурност возача приликом коришћења раскрснице,

- $f_{5}$ - сигурност пешака,

- $f_{6}$ - дозвољена брзина кретања у раскрсници,

- $f_{7}$ - исплативост раскрснице на период од 10 година и више,

- $f_{8}$ - геометријске карактеристике приликом пројектовања раскрснице и приликом коришћења корисника,

- $f_{9}$ - издвојене траке за десно скретање.

Алтернативе које су анализиране:

- $\mathrm{A2}$ - кружна раскрсница (КР)

- $\mathrm{A} 1$ - турбо кружна раскрсница (ТКР)

Након дефинисаних свих потребних параметара, приступамо изради анализе.

Вредности су дефинисане нумеричким бројевима 0 и 1, што представља значајно олакшање приликом вредновања алтернативних решења и тиме смањујемо велике рачунске операције. Вредност 1 се додељује алтернативи која има предност над алтернативом којом је поредимо и њој додељујемо вредност 0 .

Табела 1. Дефинисане критеријумске функиије са алтернативама

\begin{tabular}{|l|r|r|r|r|r|c|}
\hline krit.fun/alter. & \multicolumn{1}{|c|}{$\mathrm{A}^{1}$} & \multicolumn{1}{|c|}{$\mathrm{fi}^{+}$} & \multicolumn{1}{c|}{$\mathrm{fi}$} & \multicolumn{1}{c|}{$\mathrm{Di}$} & jed \\
\hline $\mathrm{f} 1$ & 78.2 & 100 & 78.2 & 100 & -21.8 & $\%$ \\
\hline $\mathrm{f} 2$ & 0 & 1 & 0 & 1 & -1 & $/$ \\
\hline $\mathrm{f} 3$ & 4 & 6 & 4 & 6 & -2 & kom \\
\hline $\mathrm{f} 4$ & 1 & 0 & 0 & 1 & -1 & $/$ \\
\hline $\mathrm{f} 5$ & 1 & 0 & 0 & 1 & -1 & $/$ \\
\hline $\mathrm{f} 6$ & 0 & 1 & 0 & 1 & -1 & $/$ \\
\hline $\mathrm{f} 7$ & 1 & 0 & 0 & 1 & -1 & $/$ \\
\hline $\mathrm{f} 8$ & 0 & 1 & 0 & 1 & -1 & $/$ \\
\hline $\mathrm{f} 9$ & 1 & 0 & 0 & 1 & -1 & $/$ \\
\hline
\end{tabular}

Капацитет раскрсница $\left(f_{1}\right)$ је представљен у \% и примећује се да турбо кружна раскрсница (А1) има већи капацитет него класична кружна раскрсница (А2) и то за $21,8 \%$.

Број конфликтних и колозионих тачака $\left(f_{3}\right)$ је представљен у јединици [kom], jep у турбо кружној раскрсници (A1) је то смањено и сведено је на 4 тачке, док је у кружној раскрсници (А2) сведено на 6 тачака. Остали критеријуми су изражени нумеричким бројевима 0 и 1 у зависности од предности једне алтернативе у односу на другу алтернативу.

Табела 2. Појединачна ранг листа

\begin{tabular}{|l|r|r|}
\hline krit.fun/alter. & \multicolumn{1}{|c|}{ A1 } & \multicolumn{1}{|c|}{ A2 } \\
\hline f1 & 1 & 2 \\
\hline f2 & 2 & 1 \\
\hline f3 & 1 & 2 \\
\hline f4 & 1 & 2 \\
\hline f5 & 1 & 2 \\
\hline f6 & 2 & 1 \\
\hline f7 & 1 & 2 \\
\hline f8 & 2 & 1 \\
\hline f9 & 1 & 2 \\
\hline
\end{tabular}

Табела 3. Решење за све критеријуме $(p=1)$

\begin{tabular}{|c|c|c|}
\hline alter. rešenja & A1 & $\mathrm{A} 2$ \\
\hline \multirow{9}{*}{$(\mathrm{fi}+)-(\mathrm{fij})$} & 0.0 & -21.8 \\
\hline & -1.0 & 0.0 \\
\hline & 0.0 & -2.0 \\
\hline & -1.0 & 0.0 \\
\hline & -1.0 & 0.0 \\
\hline & 0.0 & -1.0 \\
\hline & -1.0 & 0.0 \\
\hline & 0.0 & -1.0 \\
\hline & -1.0 & 0.0 \\
\hline \multirow{9}{*}{$((\mathrm{fi}+)-(\mathrm{fij})) / \mathrm{Di}$} & 0.0 & 1.0 \\
\hline & 1.0 & 0.0 \\
\hline & 0.0 & 1.0 \\
\hline & 1.0 & 0.0 \\
\hline & 1.0 & 0.0 \\
\hline & 0.0 & 1.0 \\
\hline & 1.0 & 0.0 \\
\hline & 0.0 & 1.0 \\
\hline & 1.0 & 0.0 \\
\hline$\Sigma((\mathrm{fi}+)-(\mathrm{fij})) / \mathrm{Di}$ & 5.0 & 4.0 \\
\hline $\begin{array}{l}\text { redosled } \\
\text { alter.rešenja }\end{array}$ & 2 & 1 \\
\hline
\end{tabular}

Табела 4. Решење за све критеријуме $(p=2)$

\begin{tabular}{|c|c|c|}
\hline alter. rešenja & $\mathrm{A} 1$ & $\mathrm{~A} 2$ \\
\hline \multirow{4}{*}[((\mathrm{fi}+)-(\mathrm{fi}-))/\mathrm{Di}]{$^{2}$} & 0.0 & 1.0 \\
\cline { 2 - 3 } & 1.0 & 0.0 \\
\cline { 2 - 3 } & 0.0 & 1.0 \\
\cline { 2 - 3 } & 1.0 & 0.0 \\
\cline { 2 - 3 } & 1.0 & 0.0 \\
\cline { 2 - 3 } & 1.0 & 1.0 \\
\hline \multirow{2}{\Sigma}[((\mathrm{fi}+)-(\mathrm{fi}-))/\mathrm{Di}]{$^{2}$} & 0.0 & 0.0 \\
\hline \multirow{2}{*}{$\begin{array}{c}\text { redosled } \\
\text { alter.rešenja }\end{array}$} & 1.0 & 0.0 \\
\hline
\end{tabular}

Табела 5. Решење за све критеријуме $(p=\infty)$

\begin{tabular}{|c|c|c|}
\hline alter.rešenja & $\mathrm{A} 1$ & $\mathrm{~A} 2$ \\
\hline $\mathrm{max}(\mathrm{fi}+$ )-(fij)/Di & 1.0 & 1.0 \\
\hline $\begin{array}{c}\text { redosled } \\
\text { alter.rešenja }\end{array}$ & 2 & 1 \\
\hline
\end{tabular}

Компромисно рангирање се врши помоћу одређених формула:

$$
\begin{gathered}
S_{j}=\sum \frac{f_{i}^{+}-f_{i j}}{f_{i}^{+}-f_{i}^{-}} \quad \text { за } \quad(p=1) \\
R_{j}=\max \frac{\left(f_{i}^{+}-f_{i j}\right)}{f_{i}^{+}-f_{i}^{-}} \quad \text { за } \quad(p=\infty) \\
S^{*}=\min S_{j} \quad R^{*}=\min R_{j} \\
Q_{j}=\frac{\left(S_{j}-S^{*}\right)}{\left(S^{-}-S^{*}\right)}+\frac{\left(R_{j}-R^{*}\right)}{\left(R^{-}-R^{*}\right)} \\
v_{2}=1-v_{1}
\end{gathered}
$$


Коначно рангирање се одређује помоћу мере $Q_{j}$ :

$$
\boldsymbol{Q}_{j}=\boldsymbol{v}_{1} * \frac{\left(\boldsymbol{S}_{\boldsymbol{j}}-\boldsymbol{S}^{*}\right)}{\left(\boldsymbol{S}^{-}-\boldsymbol{S}^{*}\right)}+\boldsymbol{v}_{\mathbf{2}} * \frac{\left(\boldsymbol{R}_{\boldsymbol{j}}-\boldsymbol{R}^{*}\right)}{\left(\boldsymbol{R}^{-}-\boldsymbol{R}^{*}\right)}
$$

\section{Одређивање редоследа алтернативних решења са истим тежинским коефицијетима}

Исти тежински коефицијенти $(w=0,111)$

Табела 6. Добијање редоследа алтернатива истих тежинских коефииијената

\begin{tabular}{|c|c|c|c|c|c|}
\hline & A1 & A2 & $\begin{array}{l}\mathrm{S}+ \\
\mathrm{R}+\end{array}$ & $\begin{array}{l}\text { S- } \\
\text { R- }\end{array}$ & $\begin{array}{l}\text { DS } \\
\text { DR }\end{array}$ \\
\hline $\begin{array}{c}\mathrm{Sj}(p=1) \\
\operatorname{Rj}(p=\infty)\end{array}$ & $\begin{array}{l}5.0 \\
1.0\end{array}$ & $\begin{array}{l}4.0 \\
1.0\end{array}$ & $\begin{array}{l}4.0 \\
1.0\end{array}$ & $\begin{array}{l}5.0 \\
1.0\end{array}$ & $\begin{array}{l}1.0 \\
0.0\end{array}$ \\
\hline $\begin{array}{c}(\mathrm{Sj}-\mathrm{S}+) / \mathrm{DS} \\
(\mathrm{Rj}-\mathrm{R}+) / \mathrm{DR}\end{array}$ & $\begin{array}{l}1 \\
0\end{array}$ & $\begin{array}{l}0 \\
0\end{array}$ & & & \\
\hline $\begin{array}{l}Q \mathrm{Qj}(v=0.0) \\
Q j(v=1.0)\end{array}$ & $\begin{array}{l}0 \\
1\end{array}$ & $\begin{array}{l}0 \\
0\end{array}$ & & & \\
\hline
\end{tabular}

Табела 7. Редослед алтернативних решења истих тежинских коефииијената

\begin{tabular}{|c|c|c|}
\hline & A1 & A2 \\
\hline$v=0.0$ & 1 & 2 \\
\hline$v=1.0$ & 2 & 1 \\
\hline
\end{tabular}

На основу спроведене анализе, добијамо да је коначно решење избора типа кружне раскрснице ТУРБО КРУЖНА РАСКРСНИЦА, без обзира да ли се ради о истим или разичитим тежинским коефицијентима. На основу свих задатих тежинских коефицијената добијамо тип кружне раскрснице која испуњава услове у погледу свих девет наведених функција које смо окарактерисали кроз квантативне и квалитативне показатеље.

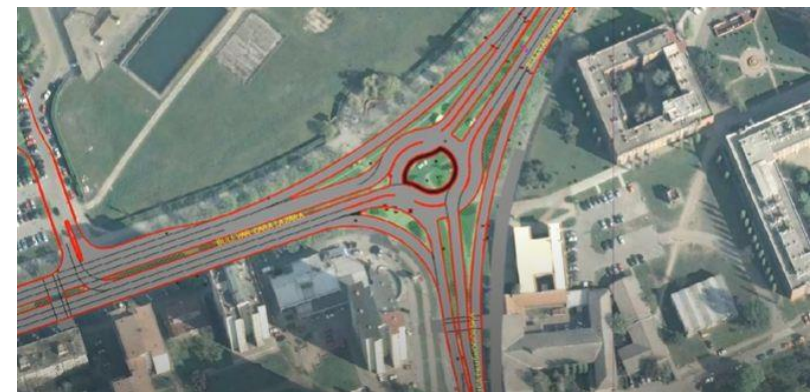

Слика 2. Идејно решење турбо кружне раскринице на углу Булевара ичара Лазара и Фрушкогорске улище

\section{0. ЗАКљУЧАК}

Кружне раскрснице постале су учинковите у решавању проблема на местима укрштања саобраћајних токова, како у свету, тако и код нас.

Како класичне кружне раскрснице најопштије можемо поделити на једнотрачне и двотрачне кружне раскрснице, двотрачне кружне раскрснице су због веће пропусне моћи чешће у примени.

Ако упоредимо ове две раскрснице са аспекта саобраћајне сигурности и протока саобраћаја, примећујемо да због већег броја конфликтних тачака које има двотрачна кружна раскрсница у односу на једнотрачну кружну раскрсницу, па самим тим двотрачне кружне раскрснице пружају мању саобраћајну сигурност, али имају већи проток саобраћаја. Као избор решења који би задовољио сигурносне елементе и елементе про- пусне моћи је турбо кружна раскрсница. Овај тип кружне раскрснице даје најбоље резултате јер су саобраћајне траке кружног коловоза међусобно раздвојене узвишеним ивичњацима и тиме се сигурност учесника у саобраћају повећава.

Међутим са економског становишта, трошкови изградње турбо кружне раскрснице су за око $15 \%$ већи од трошкова изградње конвенционалне кружне раскрснице, такође трошкови одржавања турбо кружних раскрсница су већи. Без обзира на веће трошкове изградње и одржавања, турбо кружне раскрснице дају далеко већу добит јер ће се њиховом изградњом повећати саобраћајна безбедност и тиме смањити друштвени трошкови изазвани саобраћајним несрећама.

На основу примењене вишекритеријумске оптимизације и спроведене методе итеративног компромисног рангирања (ИКОР) у којој су учествовали критеријуми капацитета, сигурности, геометрије и економичности, приликом избора решења типа кружне раскрснице за исту локацију на углу Булевара цара Лазара и Фрушкогорске улице, као решење добили смо да је турбо кружна раскрсница боља алтернатива од класичне кружне раскрснице.

Будућа турбо кружна раскрсница која је прва у Новом Саду, а и у Србији ће се даљом експанзијом проширити и на остале градове доносећи многе предности којих код класичне кружне раскрснице нема.

\section{1. ЛИТЕРАТУРА}

[1] Priručnik za projektovanje puteva u republici SrbijiJavno preduzeće Putevi Srbije, Beograd, 2012

[2] Kenjić Z., - Kružne raskrsnice - Rotori, Priručnik za planiranje i projektovanje, Udruženje konsultanata inženjera Bosne i Hercegovine, Sarajevo, 2009

[3] Cvetko T. - Smjernice za projektiranje kružnih raskrižja sa spiralnim tokom kružnog kolnika na državnim cestama, Građevinski fakultet sveučilišta u Rijeci, Rijeka, 2014

[4] Orozović S.,--OPTIMIZACIJA SISTEMA, Građevinski fakultet Univerziteta u Beogradu, Beograd, 1992

[5] Nikolić I. i Božilović S., - Optimizacija - Višeciljno $i$ Višeatributivno odlučivanje - Primena softvera Expert Choise u problemu realokacije kompanije, Fakultet za graditeljski menadžment, Beograd, 2010

\section{Кратка биографија:}

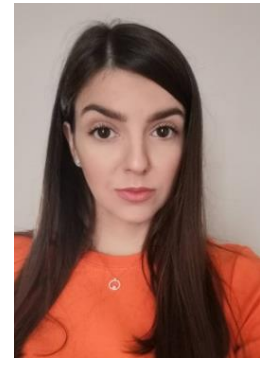

Далиа Штрбац рођена у Книну 1989. год. октобра 2008. године уписује основне студије на Факултету техничких наука из области Грађевинарства. У јула 2019. године стиче звање дипломираног грађевинског инжењера на одсеку за путеве, железнице и аеродроме. Мастер рад на Факултету техничких наука из области градских саобраћајница одбранила је у јуну 2021. године. 